\title{
Congenital and Perinatal Cytomegalovirus Infections in the Neonatal Period: Case Series
}

\author{
Yenidoğan Döneminde Konjenital ve \\ Perinatal Sitomegalovirüs Enfeksiyonu: Olgu Serisi
}

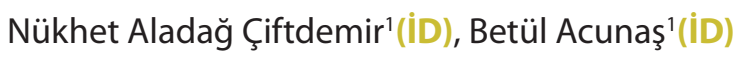 \\ ${ }^{1}$ Division of Neonatology, Department of Pediatrics, Trakya University School of Medicine, Edirne, Turkey
}

Cite this article as: Aladağ Çiftdemir N, Acunaş B. Congenital and perinatal cytomegalovirus infections in the neonatal period: Case series. J Pediatr Inf 2020;14(1):e21-e26.

*The study was presented as a poster in "XXVI European Congress Perinatal Medicine".

\begin{abstract}
Objective: Cytomegalovirus infection when diagnosed in the first three weeks of life is generally accepted to be indicative of a "congenital" or "vertical" infection, whereas when cytomegalovirus infection is diagnosed after the first three weeks of life, it is generally considered as "perinatal" or "horizontal" infection. Since diagnosis of either a congenital or perinatal cytomegalovirus infection is challenging, as well as their treatment, this study aimed to address the issues about the diagnosis and treatment of congenital/perinatal cytomegalovirus infection by presenting a series of infants followed-up in our neonatal intensive care unit.

Material and Methods: Medical records of newborn infants with congenital/perinatal cytomegalovirus infection who were admitted to our level III neonatal intensive care unit between August 2015 and May 2018 were evaluated retrospectively. Only infants who received cytomegalovirus-specific therapy were included.

Results: Out of 1039 infants admitted to the neonatal intensive care unit during the study period, $8(0.8 \%)$ were diagnosed and treated for congenital/perinatal cytomegalovirus infections. All of them were preterm infants. Four infants found to be CMV positive during the first 21 days of life were diagnosed as congenital cytomegalovirus infection, while a perinatal and congenital infection differentiation could not be made in the rest of the patients. Anemia (75\%), thrombocytopenia (62.5\%) and hearing loss $(62.5 \%)$ were the most common findings in patients with congenital/perinatal infection. None of the infants had chorioretinitis.
\end{abstract}

Öz

Giriş: Sitomegalovirüs enfeksiyonu hayatın ilk üç haftasında tanı aldığında genellikle konjenital ya da vertikal enfeksiyon düşündürürken, hayatın ilk üç haftasından sonra tanı alan sitomegalovirüs enfeksiyonları genellikle perinatal horizontal enfeksiyonlar olarak değerlendirilir. Hem konjenital hem de perinatal sitomegalovirüs enfeksiyonlarının tanısı ve tedavisi zor olduğundan, bu çalışmada yenidoğan yoğun bakım ünitesinde izlediğimiz olgu serisini sunarak konjenital/perinatal sitomegalovirüs enfeksiyonlarının tanısı ve tedavisindeki önemli noktaları vurgulamak istedik.

Gereç ve Yöntemler: Üçüncü düzey yenidoğan yoğun bakım ünitesine Ağustos 2015-Mayıs 2018 tarihleri arasında konjenital/perinatal sitomegalovirüs enfeksiyonu nedeniyle yatan yenidoğanların tıbbi kayıtları retrospektif olarak değerlendirildi. Sadece sitomegalovirüs enfeksiyonuna yönelik spesifik tedavi alan bebekler çalışmaya dahil edildi.

Bulgular: Çalışma sürecinde yenidoğan yoğun bakım ünitesine yatan 1039 bebekten $8(\% 0.8)^{\prime} i$ konjenital/perinatal sitomegalovirüs enfeksiyonu tanısıyla tedavi edildi. Tüm olgular preterm idi. Hayatın ilk 21 günü içinde CMV-DNA pozitif olduğu saptanan dört bebek konjenital sitomegalovirüs enfeksiyonu olarak tanı alırken diğer olgularda konjenital ve perinatal enfeksiyon ayrımı yapılamadı. Konjenital/perinatal enfeksiyonu olanlarda en sık görülen bulgular, anemi (\%75), trombositopeni (\%62.5) ve işitme kaybı (\%62.5) idi. Hiçbir bebekte koryoretinit saptanmadı. Mikrosefalik 2 (\%25) bebekte intrakraniyal kalsifikasyonlar

Correspondence Address/Yazışma Adresi

Nükhet Aladağ Çiftdemir

Trakya Üniversitesi Tıp Fakültesi,

Çocuk Sağlığı ve Hastalıkları Anabilim Dalı,

Neonatoloji Bilim Dalı,

Edirne-Türkiye

E-mail: nukhetaladag@yahoo.com 
Two infants (25\%) with microcephaly had intracranial calcifications. Sepsis-like findings were present in three very preterm infants (37.5\%). Cytomegalovirus-IgM was positive in all 8 infants with infection; however, serum CMV-DNA was positive in seven of them. All infants with moderate to severe symptoms were treated with ganciclovir and/or valganciclovir. Viral load decreased dramatically at the end of the treatment period.

Conclusion: Cytomegalovirus infection, either congenital or perinatal, is a greater risk especially for preterm infants who may warrant and benefit from newborn cytomegalovirus screening, early detection, and effective antiviral treatment.

Keywords: Cytomegalovirus, congenital infection, perinatal infection, preterm, newborn

\section{Introduction}

Among the congenital infections caused by viruses, cytomegalovirus (CMV) is the most common causative agent, and congenital CMV infections may affect approximately $2 \%$ of newborn infants. Untoward consequences of congenital CMV infections are critical as they may include hearing impairment, cognitive deficits, seizures, and death (1). Although the importance of congenital CMV infection is obvious, the majority of maternal and fetal infections are not identified even in developed countries unless there is a screening program implemented. This may be due to the fact that only $10 \%$ of the infants with CMV infections manifest clinical symptoms $(2,3)$. Furthermore, making a diagnosis of congenital/perinatal CMV infection is difficult because the sample from the infant collected on day 21 before birth should be negative and the sample collected from the same infant 21 days after birth should be positive in order to diagnose postnatal infection (4). Infection acquired during the intrapartum period from maternal cervical secretions or in the postpartum period from human milk is not usually associated with clinical illness in term infants. In preterm infants; however, postpartum infection resulting from human milk or from transfusion from CMV-seropositive donors has been associated with hepatitis, interstitial pneumonia, hematologic abnormalities including thrombocytopenia and leukopenia, and a viral sepsis syndrome $(5,6)$. Antiviral therapy with ganciclovir and/or valganciclovir has been reported to be beneficial for improving neurodevelopmental sequelae and hearing outcomes of congenital CMV infection; however, treatment outcomes are not well reported $(7,8)$. Furthermore, diagnostic and therapeutic knowledge on postnatal CMV infections need to be improved to discriminate infants who profit from antiviral therapy from those where CMV shedding is solely a bystander event (9).

Therefore, in this article, we present a series of infants diagnosed and treated with congenital/perinatal CMV infection followed-up in our level III neonatal intensive care unit (NICU) in order to discuss and address the issues met in the diagnosis and treatment of congenital/perinatal CMV infection in the light of the literature. bulunmaktaydı. İleri derecede preterm olan 3 (\%37.5) bebekte sepsis benzeri bulgular saptandı. Enfekte olan tüm olgularda CMV-IgM pozitifti ancak, serum CMV-DNA'nın yedi bebekte pozitif olduğu görüldü. Orta ve ciddi düzeylerde semptomları olan bebekler gansiklovir ve/veya valgansiklovirle tedavi edildi. Tedavi sürecinin sonunda virüs yükünün dramatik olarak düştüğü görüldü.

Sonuç: Hem konjenital hem de perinatal sitomegalovirüs enfeksiyonu özellikle preterm bebekler için büyük bir risk taşır. Preterm doğan bebeklerin sitomegalovirüs taraması, erken tanı ve etkin antiviral tedaviden fayda görecekleri kesindir.

Anahtar Kelimeler: Anne sütü, sitomegalovirüs, konjenital enfeksiyon, yenidoğan, perinatal enfeksiyon

\section{Materials and Methods}

\section{Design of the Study}

Medical records of newborn infants with congenital/perinatal CMV infection who were hospitalized in our level III NICU in the period from August 2015 to May 2018 were evaluated retrospectively. Demographic features, clinical and laboratory findings (complete blood count, liver function tests, serum bilirubin levels, electrolytes, serum CMV IgM, CMV-PCR in serum and/or urine, breast milk), cranial imaging and hearing test results, the presence of chorioretinitis and treatment modalities were recorded. CMV-lgM antibody in serum were determined using microenzyme immunoassay system (ELISA). Quantification of the viral load of CMV using real-time polymerase chain reaction (PCR) tests in the serum, urine, and breast milk samples was performed before starting the treatment. The diagnosis of congenital CMV infection was made when the sample collected in the first 21 days of life was positive. Perinatal CMV infection was defined if the patients were diagnosed after postnatal third week (6). Sepsis-like illness was diagnosed based on age-specific criteria (10). The infants included in our study were fed with a non-specified combination of fresh and/ or frozen breastmilk from their own mothers following the procedures established in our NICU. One infant was fed with preterm formula. In order to reduce CMV infection acquired through transfused blood products, infants in our institution receive routinely leucocyte-reduced and irradiated blood products. Infants with moderately to severely symptomatic congenital/perinatal CMV infection were treated with gancyclovir and/or valgancyclovir (11). Oral valganciclovir was preferred if the patient's clinic status was stable and on full enteral feeding. Otherwise oral valganciclovir was started after two weeks of gancyclovir treatment.

\section{Statistical Analysis}

Research data were analyzed by SPSS 23.0 statistical package program. Descriptive statistics were presented as mean $( \pm S D)$, median (minimum, maximum), frequency distribution and percentage.

This study was approved by Trakya University Ethics Committee (2019/237). 


\section{Results}

There were $8(0.8 \%)$ infants with congenital/perinatal CMV infection out of 1039 infants admitted to our NICU during that period. Demographic features, clinical characteristics, laboratory findings, management procedures, and treatment outcomes of infants with CMV infection are shown in Table 1. Mean weight at birth was $1365 \mathrm{~g}( \pm 578)$ and mean gestational age was $30( \pm 4.5)$ weeks. Median time of diagnosis was 31.5 days (2-108 days). The most common findings were anemia (75\%), thrombocytopenia (62.5\%), and hearing loss $(62.5 \%)$. None of the infants had chorioretinitis. Among the infants with CMV infections, 2 (25\%) infants with microcephaly had intracranial calcifications and $3(37.5 \%)$ very preterm infants showed sepsis-like findings whose mothers experienced preterm rupture of the membranes. Serum CMV-IgM was positive in all infants. Seven infants were positive for CMV-DNA in serum sample. Median copy numbers of CMV-DNA found by PCR test were 12.000 .000 copy $/ \mathrm{mL}(859.000-117.000 .000)$ in the urine and $39.500 \mathrm{copy} / \mathrm{mL}(1400-330.000)$ in the serum. Mean copy numbers of CMV-DNA in the breast milk of 5 mothers was $660.596 \mathrm{copy} / \mathrm{mL}$ (2940-2.760.000). Seven infants were breastfed. Blood transfusion was present in four infants. Four infants who were found to be CMV positive during the first 21 days of life were diagnosed with congenital CMV infection, while a perinatal and congenital infection differentiation could not be made in the rest of the patients. Six infants were treated initially with ganciclovir followed by valganciclovir for 6 months. One infant died while receiving ganciclovir treatment. One infant was treated with oral valganciclovir since the patient's clinic status was stable and on full enteral feeding at the time of diagnosis. After this treatment, viral load decreased dramatically and three out of five infants with abnormal hearing test results showed normalization. In the other two infants, hearing improved during follow up. One infant with sepsis-like illness died, and two infants developed neuromotor retardation (Table 1).

\section{Discussion}

Among all congenital infections in the world, CMV infections are the most common, creating significant risks for infected newborn infants. The estimated incidence of congenital CMV infections varies in developed and developing countries with rates in all live births ranging from 0.6 to $0.7 \%$ compared to a range between 1 and 5\%, respectively. The high rates of estimated incidence in developing countries are associated with the high rates of maternal seroprevalence in these countries (5). The rate of congenital CMV infection from our country was reported as $0.2 \%$ (12). In our NICU, parallel to the reports in the literature, the incidence of CMV infection was found to be $0.8 \%$; however, it should be noted that this is the incidence of symptomatic congenital/perinatal CMV infections and CMV screening is not performed routinely in our
NICU. Universal CMV screening of pregnant women is not recommended by national public health bodies in any country (10). With implemented CMV screening programs applied to all infants in NICUs, the incidence of congenital CMV infection has been reported in the range from $0.8 \%$ to $6.8 \%(2,3)$.

In the literature, the most common findings associated with the CMV infections in the newborn infants are reported as petechia, jaundice, hepatomegaly, splenomegaly, microcephaly, hearing loss, hypotonia/lethargy, chorioretinitis, and hemolytic anemia $(5,6,13)$. Thrombocytopenia and cholestatic hepatitis were the most common findings in the case series of Ulubas Isik et al. whereas prolonged jaundice was the most frequent finding in the series of Çelikel et al. $(12,14)$. The most frequent findings in our series were anemia, thrombocytopenia, and hearing loss. Jaundice, microcephaly, elevated liver enzyme levels, presence of intracranial calcification, intrauterine growth retardation were other findings.

Preterm infants ( $<32$ weeks of gestation) with symptomatic congenital CMV are more likely to have pneumonitis, signs of viral sepsis, thrombocytopenia, and co-infections, and they are less likely to have microcephaly or intracranial calcifications compared to term neonates $(2,4,13)$. In the case series of Ulubas Isik et al., $75 \%$ of the cases were preterm (12). In our series, all of the infants were $<37$ weeks and 5 of them were $<32$ weeks gestation. Two infants with microcephaly and intracranial calcifications were $>32$ weeks gestation. The significance of these findings is that the symptoms in congenital or perinatal CMV infection can be severe in preterm infants. In extremely low birth weight infants, the most common route of transmission after birth is breast milk. In the literature, the rate of CMV transmission via breast milk was reported to be $38 \%$ by Hamprecht et al. (15). The same study reported that hepatopathy, neutropenia, thrombocytopenia, and sepsis-like illness developed in $48 \%$ of the infected infants and those severe clinical symptoms including sepsis-like illness were seen up to $12 \%$ of the affected infants. Lanzieri et al. conducted a meta-analysis on preterm infants, delivered earlier than $<32$ weeks gestation or had a birth weight $<1500$ grams (16). This meta-analysis reported that; of the fresh breast-fed infants from CMV positive mothers, 19\% acquired CMV and 4\% developed sepsis-like illness due to CMV infection. Josephon et al. noted that the risk of acquiring CMV infection for the infants in the postnatal period increased with increased number of days of feeding with breast milk, high viral load of CMV in the breast milk, and early membrane rupture and reported early membrane rupture as an independent predictor of CMV transmission from the seropositive mothers to the affected infants; however, the same study did not find an association between the mode of delivery and mother-to-infant transmission (17). In our series, we found CMV-DNA in the breast milk of five infants. Of these five infants, three developed sepsis-like illness, whose mothers experienced preterm rupture of the membranes. Although 
Table 1. Demographic features, clinical characteristics, laboratory findings, treatment and outcome of infants with congenital/perinatal cytomegalovirus infection

\begin{tabular}{|c|c|c|c|c|c|c|c|}
\hline $\begin{array}{l}\text { Case } \\
\text { no }\end{array}$ & $\begin{array}{c}\text { GA (weeks)/ } \\
\text { Mode of } \\
\text { delivery }\end{array}$ & BW (g) & $\begin{array}{c}\text { Day of } \\
\text { diagnosis }\end{array}$ & History and clinical findings & Laboratory findings & Treatment & Outcome \\
\hline 1 & $35 / C / S$ & 1610 & 2 & $\begin{array}{l}\text { Oligohydroamnios } \\
\text { IUGR } \\
\text { Breast milk nutrition } \\
\text { Microcephaly } \\
\text { Intracranial calcification } \\
\text { Hearing loss }\end{array}$ & $\begin{array}{l}\text { Thrombocytopenia } \\
\text { Anti-CMV IgM (+) } \\
\text { Serum CMV DNA (+) } \\
\text { (330.000 copies/mL) }\end{array}$ & $\begin{array}{l}\text { Ganciclovir + } \\
\text { Valganciclovir }\end{array}$ & $\begin{array}{l}\text { Discharged } \\
\left(51^{\text {th }} \text { day }\right) \\
\text { Neuromotor } \\
\text { retardation, } \\
\text { hearing loss } \\
\text { improved }\end{array}$ \\
\hline 2 & $31 / N D$ & 1670 & 50 & $\begin{array}{c}\text { Jaundice } \\
\text { Formula nutrition }\end{array}$ & $\begin{array}{c}\text { Hemolytic anemia } \\
\text { Elevated direct and indirect serum bilirubin } \\
\text { Direct coombs }(+) \\
\text { Anti-CMV IgM }(+) \\
\text { Urine CMV DNA }(+) \\
(859.000 \text { copies } / \mathrm{mL}) \\
\end{array}$ & $\begin{array}{l}\text { Ganciclovir + } \\
\text { Valganciclovir }\end{array}$ & $\begin{array}{l}\text { Discharged } \\
\left(70^{\text {th }} \text { day }\right)\end{array}$ \\
\hline 3 & $27 / C / S$ & 1020 & 21 & $\begin{array}{c}\text { PROM, } \\
\text { Breast milk nutrition } \\
\text { Blood transfusion } \\
\text { Sepsis-like illness } \\
\text { Hearing loss }\end{array}$ & $\begin{array}{c}\text { Anemia, Thrombocytopenia } \\
\text { CRP }(+) \\
\text { Anti-CMV IgM (+) } \\
\text { Serum CMV DNA (+) } \\
\text { (34.800 copies/mL) } \\
\text { Breast milk CMV DNA (+) } \\
\text { (59.200 copies } / \mathrm{mL})\end{array}$ & $\begin{array}{l}\text { Ganciclovir + } \\
\text { Valganciclovir }\end{array}$ & $\begin{array}{c}\text { Discharged } \\
\left(76^{\text {th }} \text { day), hearing }\right. \\
\text { loss improved }\end{array}$ \\
\hline 4 & $26 / C / S$ & 900 & 66 & $\begin{array}{c}\text { Anemia } \\
\text { Breast milk nutrition } \\
\text { Blood transfusion }\end{array}$ & $\begin{array}{c}\text { Anemia, } \\
\text { Anti-CMV IgM (+) } \\
\text { Serum CMV DNA (+) } \\
\text { (63.200 copies/mL) } \\
\text { Urine CMV DNA }(+) \\
\text { (105.000.000 copies/mL) }\end{array}$ & Valganciclovir & $\begin{array}{l}\text { Discharged } \\
\left(88^{\text {th }} \text { day }\right) \\
\text { Neuromotor } \\
\text { retardation }\end{array}$ \\
\hline 5 & $25 / \mathrm{C} / \mathrm{S}$ & 800 & 108 & $\begin{array}{c}\text { PROM } \\
\text { Breast milk nutrition } \\
\text { Blood transfusion } \\
\text { Sepsis-like ilness } \\
\text { Hepatitis } \\
\text { Pneumonia }\end{array}$ & $\begin{array}{c}\text { Anemia, neutropenia } \\
\text { Thrombocytopenia } \\
\text { CRP }(+) \\
\text { Elevated liver transaminases } \\
\text { Anti-CMV IgM }(+) \\
\text { Serum CMV DNA }(+) \\
\text { (4780 copies/mL) } \\
\text { Breast milk CMV DNA (+) } \\
(2940 \text { copies } / \mathrm{mL})\end{array}$ & Ganciclovir & $\begin{array}{c}\text { Died } \\
\left(130^{\text {th }} \text { day }\right)\end{array}$ \\
\hline 6 & $26 / \mathrm{C} / \mathrm{S}$ & 975 & 42 & $\begin{array}{c}\text { PROM } \\
\text { Breast milk nutrition } \\
\text { Blood transfusion } \\
\text { Sepsis-like ilness } \\
\text { Hearing loss }\end{array}$ & $\begin{array}{c}\text { Anemia } \\
\text { Elevated liver transaminases } \\
\text { CRP }(+) \\
\text { Anti-CMV IgM }(+) \\
\text { Urine CMV DNA }(+) \\
(12.000 .000 \text { copies/mL) } \\
\text { Serum CMV DNA }(+) \\
\text { (1400 copies/mL) } \\
\text { Breast milk CMV DNA (+) } \\
\text { (8410 copies/mL) }\end{array}$ & $\begin{array}{l}\text { Ganciclovir/ } \\
\text { Valganciclovir }\end{array}$ & $\begin{array}{l}\text { Discharged } \\
\left(75^{\text {th }} \text { day) }\right. \\
\text { hearing loss } \\
\text { improved }\end{array}$ \\
\hline 7 & $36 / N D$ & 2540 & 21 & $\begin{array}{l}\text { Breast milk nutrition } \\
\text { Prolonged jaundice } \\
\text { Microcephaly } \\
\text { Cholestatic hepatitis } \\
\text { Intracranial calcification } \\
\text { Hearing loss }\end{array}$ & $\begin{array}{c}\text { Thrombocytopenia } \\
\text { Elevated direct and indirect serum bilirubin } \\
\text { Anti-CMV IgM (+) } \\
\text { Serum CMV DNA (+) } \\
\text { (39.500 copies/mL) } \\
\text { Urine CMV DNA }(+) \\
(2.960 .000 \text { copies } / \mathrm{mL}) \\
\text { Breast milk CMV DNA (+) } \\
\text { (2.760.000 copies } / \mathrm{mL})\end{array}$ & $\begin{array}{c}\text { Ganciclovir/ } \\
\text { Valganciclovir }\end{array}$ & $\begin{array}{l}\text { Discharged } \\
\left(38^{\text {th }} \text { day }\right) \\
\text { hearing loss } \\
\text { improved }\end{array}$ \\
\hline 8 & $34 / \mathrm{C} / \mathrm{S}$ & 1405 & 2 & $\begin{array}{c}\text { IUGR } \\
\text { Breast milk nutrition } \\
\text { Hearing loss }\end{array}$ & $\begin{array}{c}\text { Thrombocytopenia } \\
\text { Elevated indirect serum bilirubin } \\
\text { Anti-CMV IgM }(+) \\
\text { Serum CMV DNA }(+) \\
\text { (41.800 copies/mL) } \\
\text { Urine CMV DNA (+) } \\
\text { (117.000.000 copies } / \mathrm{mL}) \\
\text { Breast milk CMV DNA (+) } \\
\text { (480.000 copies } / \mathrm{mL})\end{array}$ & $\begin{array}{l}\text { Ganciclovir/ } \\
\text { Valganciclovir }\end{array}$ & $\begin{array}{l}\text { Discharged } \\
\left(17^{\text {th }} \text { day), }\right. \\
\text { hearing loss } \\
\text { improved }\end{array}$ \\
\hline
\end{tabular}


the exact mechanism is unknown, there are arguments for local disease reactivation in mammary glands which allow viral shedding without systemic reactivation of the disease regarding both symptoms and laboratory measures (negative serum HCMV-IgM, negative viruria) (18). Hamprecht et al. have found that viral reactivation in seropositive mothers was $96 \%$. The cumulative rate of transmission was $37 \%$ (15). All of our infants were breastfed except one infant. CMV-DNA was positive in breast milk of five cases. Several strategies have been developed to inactivate CMV in breast milk. American Academy of Pediatrics recognize long and short-term pasteurization as safe techniques because of their efficacy in viral inactivation for premature neonates born less than 32 weeks of gestational age from CMV IgG positive mothers. It is also reported that freezing reduces viral load without eliminating it (19). Unfortunately, we can only use freezing in our NICU. Besides, CMV infection may be transmitted to the neonates in NICU via blood transfusions. This phenomenon was avoided successfully with the use of CMV-IgG negative blood transfusions (5). In our series, four infants underwent blood transfusions. Donors in blood banks do not undergo a routine screening for CMV-IgG in our country.

Ganciclovir and valganciclovir are the most commonly used antiviral drugs for the treatment of symptomatic congenital CMV infection, and it has been detected to be beneficial for improving hearing and developmental outcomes $(7,8)$. Schuster et al. have demonstrated that antiviral treatment was beneficial in the two groups they divided into as symptomatic congenital and probabaly postnatal infection (9). American Academy of Pediatrics recommends that therapy can be accomplished using oral valganciclovir for the entire treatment course because drug exposure following appropriate dosing of valganciclovir is the same as that achieved with intravenous ganciclovir. However if an infant is unable to absorb medications reliably from the gastrointestinal tract (e.g., because of necrotizing enterocolitis or otherboweldisorders), intravenous ganciclovir at $6 \mathrm{mg} / \mathrm{kg} /$ dose can be used initially (6). In concert with these recommendations, in our series we mostly used ganciclovir initially because all of the infants in our series were preterm and their gastrointestinal system was immature to reliably absorb the medication enterally. When we observed a significant decrease in the viral load, we continued with oral valganciclovir at $16 \mathrm{mg} / \mathrm{kg} /$ dose twice daily to complete the treatment in six months. During this period, CMV viral load decreased dramatically in all infants in our series except the one who died. At the end of this treatment, we found that hearing loss improved in all infants, and only two of them developed neuromotor retardation. The data on the value of CMV blood copy numbers for guiding therapeutic decisions in infants are incomplete, yet it appears that the extent of CMV load is associated with the risk of hearing loss. Determination of CMV load in peripheral blood before and during treatment seems advisable, both to add to the individual risk assessment and to determine the treatment response (9). Our study is important because it shows CMV-DNA copy values (serum, urine, breast-milk) in detail and emphasizes the importance of the condition as a serious problem, especially in preterm infants.

\section{Conclusion}

In conclusion, CMV infection either congenital or perinatal is a greater risk especially for preterm infants who may warrant and benefit from newborn CMV screening, early detection, and effective antiviral treatment. Nationwide guidelines are required to reduce this risk because rate of maternal seropositivity is quite high in our country.

Ethics Committe Approval: This study was approved by Trakya University Ethics Committee (2019/237).

Informed Consent: Patient concent was obtained.

Peer-review: Externally peer-reviewed.

Author Contributions: Concept - NAC, BA; Design - NAC, BA; Supervision - BA; Materials - NAC; Data Collection and/or Processing NAC; Analysis and/or Interpretation - BA; Literature Review - NAC, BA; Writing - NAC, BA; Critical Review -NAC, BA.

Conflict of Interest: No conflict of interest was declared by the authors.

Financial Disclosure: The authors declared that this study has received no financial support.

\section{References}

1. Congenital cytomegalovirus infection: Update on treatment: Scientific

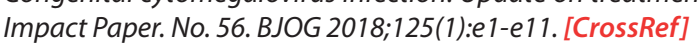

2. Miura CS, Miura E, Mombach AB, Chesky M. The prevalence of congenital cytomegalovirus infection in newborn infants at an intensive care unit in a public hospital. J Pediatr 2006;82:46-50.' [CrossRef]

3. Panhani $S$, Heinonen K. Screening for congenital cytomegalovirus infection among preterm infants born before the $34^{\text {th }}$ gestational week in Finland. Scand J Infect Dis 1994;26:375-8. [Cross Ref]|

4. Lim Y, Lyall H. Congenital cytomegalovirus-who, when, what-with and why to treat? J Infect 2017;74:89-94. [C [rossRef ] ]

5. Bardanzellu F, Fanos V, Reali A. Human breast milk-acquired cytomegalovirus infection: certainties, doubts and perspectives. Curr Pediatr Rev 2019;15:30-41. ['CrosśRéf

6. American Academy of Pediatrics. Cytomegalovirus Infection. In: Kimberlin DW, Brady MT, Jackson MA, Long SS (eds). Red Book: 2018 Report of the Committee on Infectious Diseases. $37^{\text {st }}$ ed. Itasca, IL: American Academy of Pediatrics, 2018:310-7. [CrossRef]

7. Kimberlin DW, Lin CY, Sanchez PJ, Demmler GJ, Dankner W, Shelton M, et al. Effect of ganciclovir therapy on hearing in symptomatic congenital cytomegalovirus disease involving the central nervous system: a randomized, controlled trial. J Pediatr 2003; 143:16-25. [" [Cross Ref $]_{1}^{\prime}$

8. Kimberlin DW, Jester PM, Sanchez PJ, Ahmed A, Arav-Boger R, Michaels $M G$, et al. Valganciclovir for symptomatic congenital cytomegalovirus disease. N Engl J Med 2015;372:933-43. [Cross Ref $]_{1}$

9. Schuster K, Goelz R, Speckmann C, Henneke P. Symptomatic cytomegalovirus infections in the first year of life: when is antiviral therapy conceived to be justified? Pediatr Infect Dis J 2017;36:224-7. [C C ross Reff $]_{1}$ 
10. Goldstein B, Giroir B, Randolph A; International Consensus Conference on Pediatric Sepsis. International pediatric sepsis consensus conference: definitions for sepsis and organ dysfunction in pediatrics. Pediatr Crit Care Med 2005;6:2-8. "[C CrossRef $]_{1}$

11. Rawlinson WD, Boppana SB, Fowler KB, Kimberlin DW, Lazzarotto $T$, Alain $S$, et al. Congenital cytomegalovirus infection in pregnancy and the neonate: consensus recommendations for prevention, diagnosis, and therapy. Lancet Infect Dis 2017;17:e177-88. "CrossRef]',

12. Ulubaş Işık D, Özcan B, Demirel N, Ünal S, Çelik iH, Baş AY. Case series of congenital cytomegalovirus infection in neonatal period. Gazi Med Journal 2018;9:31-3. "[Crosśéfi"

13. Marsico C, Kimberlin DW. Congenital cytomegalovirus infection: advances and challenges in diagnosis, prevention and treatment. Ital J

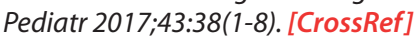

14. Çelikel E, Tezer H, Kanik-Yuksek S, Gülhan B, Ozkaya-Parlakay A, Yaralı $N$. Evaluation of 98 immunocompetent children with cytomegalovirus infection: importance of neurodevelopmental follow-up. Eur J Pediatr 2015;174:1101-7. "[CrossRef $]_{1}^{\prime}$
15. Hamprecht K, Maschmann J, Vochem M, Dietz K, Speer CP, Jahn G. Epidemiology of transmission of cytomegalovirus from mother to preterm infant by breastfeeding. Lancet 2001;357:513-8. "[C Cross Ref $]_{1}^{\prime}$

16. Lanzieri TM, Dollard SC, Josephson CD, Schmid DS, Bialek SR. Breast milk-acquired cytomegalovirus infection and disease in VLBW and premature infants. Pediatrics 2013;131:e1937-45. ['Cross Ref $]_{1}$

17. Josephson CD, Caliendo AM, Easley KA, Knezevic A, Shenv N, Hinkes MT, et al. Blood transfusion and breast milk transmission of cytomegalovirus in very low birth weight infants. JAMA Pediatr 2014;168:1054-62. [Crossief $]_{1}$

18. Hamprecht K, Maschmann J, Jahn G, Poets CF, Goelz R. Cytomegalovirus transmission to preterm infants during lactation. $J$ Clin Virol 2008;41:198-205. "[C Cross Ref $]_{1}$

19. American Academy of Pediatrics. Human Milk. In: Kimberlin DW, Brady MT, Jackson MA, Long SS (eds). Red Book: 2018 Report of the Committee on Infectious Diseases. $37^{\text {st }}$ ed. Itasca, IL: American Academy of Pediatrics, 2018:3117-20. [CrossRef] 